\title{
Technology, Poverty, and Education within the BRICS' Context
}

Submitted 30/07/20, $1^{\text {st }}$ revision $24 / 08 / 20,2^{\text {nd }}$ revision 15/09/20, accepted 30/09/20

\author{
Kunofiwa Tsaurai $^{1}$, Bester Chimbo ${ }^{2}$
}

\begin{abstract}
:
Purpose: The study investigated the impact of information and communication technology (ICT) on poverty and if education enhanced the influence of ICT in BRICS (Brazil, Russia, India, China, South Africa).

Design/Approach/Methodology: Fixed effects, pooled ordinary least squares (OLS) and panel fully modified ordinary least squares (FMOLS) were used with data ranging from 1994 to 2015 .

Findings: ICT was found to have alleviated poverty only under the fixed effects approach whilst education had a reduction effect on poverty across all the three econometric estimation techniques used. Although not statistically significant, ICT and the interaction term were found to have reduced poverty under both the pooled OLS and FMOLS. Moreover, consistent with others education was found to be important in enhancing the impact of ICT on poverty alleviation under the fixed effects in BRICS nations.

Practical Implication: BRICS nations are therefore urged to invest more in strengthening education and ICT systems in order to disentangle the people from the vicious cycle of poverty.

Originality/Value: The study is unique because to the best of the authors' knowledge, it is the first paper to explore the effect of the complementarity between ICT and education on poverty alleviation. The paper is also unique in the sense that it considered the dynamic characteristics of poverty data, commonly referred to as the vicious cycle of poverty.
\end{abstract}

Keywords: Education, poverty, BRICS, panel data.

JEL codes: I2, I3, O14.

Paper Type: Research Article.

ISSN: 2241-4754, H index 10, Q3.

\footnotetext{
${ }^{1}$ Associate Professor, Department of Finance, Risk Management and Banking, University of South Africa, South Africa, e-mail: tsaurk@unisa.ac.za

${ }^{2}$ Senior Lecturer, School of Computing, University of South Africa, South Africa, e-mail: cchimbo@unisa.ac.za;
} 


\section{Introduction}

According to Aftab and Ismail (2015), ICT drives modern knowledge-based economy and therefore it is an engine for growth and development in any country. The argument was supported by World Bank (2012) whose document further explained the positive role that ICT plays in spurring economic growth, poverty reduction and good governance. Literature is awash with arguments outlining the positive role that ICT plays in stimulating economic growth to such an extent that there is now little or no contestation against the ICT-led growth hypothesis. What is still unclear is whether or how ICT leads to poverty reduction or if the ICT-led poverty alleviation is conditional. According to Gabriels and Horn (2014), there is an increasing interest in the developmental role that ICT can play towards poverty alleviation. However, empirical research on ICT-poverty nexus is still very scant.

Consistent with Kelles-Viitanen (2003), the influence of ICT in stimulating poverty eradication has been and still a hotly debated issue which is not yet resolved. The view was shared by Haider (2017) whose study noted that it is still difficult to comprehend the role that ICT plays in alleviating the suffering of the marginalised and the poor people in the society. It is against this background that the current study explored the poverty reduction role that ICT plays in BRICS nations. Although majority of the literature argue that ICT contributes to poverty reduction, the role of education in the ICT-poverty nexus has so far been overlooked. This study is expected to help BRICS countries to develop sound (1) ICT policies that lowers poverty and (2) education development policies that ensures that ICT meaningfully contributes towards poverty reduction.

Literature on ICT-poverty nexus is characterized by a lot of conflicting arguments. Some authors believe that ICT can reduce poverty (Kim, 2014; Greenberg, 2005; Kenny, 2002; Heeks, 2010; Thomson, 2008; Kelles-Viitanen, 2003; Obayelu and Ogunlade, 2006; Etzo and Collender, 2010; Okpaku, 2006), others are of the opinion that ICT increases poverty (Jimba, 2000; Philip and Tsoi, 1988; Tambo, 2003) whilst the remainder argues that the relationship between ICT and poverty is not a linear one (Haider, 2017). Such contradictions in the literature can only be best resolved by carrying out further empirical tests, consistent with Tsaurai (2017).

Haider (2017) also revealed that the impact of ICT on poverty is not a linear one as it depends on other socio-economic factors. Quibria and Tschang (2001) noted that it is not yet clear if the poor people have the education and financial wherewithal to be able to benefit from the advantages of ICT. The view by Haider (2017) and Quibria and Tschang (2001) that the ability of ICT to deliver poverty reduction depends on other socio-economic factors, education and financial development has not been empirically tested. To the best of the author's knowledge, no study so far has investigated conditions that must be available before ICT can be able to reduce poverty. This paper contributes to literature by investigating whether education is necessary to lubricate ICT's influence on poverty alleviation in BRICS nations. 
Moreover, this is the first study to the best of the author's knowledge to focus on ICT-led poverty reduction in the context of BRICS.

Section 2 discusses the theoretical literature on the impact of ICT on poverty, section 3 is the empirical literature on ICT led poverty reduction hypothesis whilst section 4 presents and analyze the trends between ICT and poverty during the period ranging from 1994 to 2015. Research methodology and interpretation of results is discussed in section 5. Section 6 summarizes the paper.

\section{Literature Review}

\subsection{Information, Communication Technology and Poverty: Theoretical View}

There are two main theoretical views on the relationship between ICT and poverty, namely (1) the ICT led poverty reduction and (2) the ICT led poverty increase perspective. Supporters of the ICT led poverty reduction include Kim (2014), Greenberg (2005) and Kenny (2002). According to Kim (2014), ICT increases economic development directly and indirectly through accelerating gender equality, freedom of speech and political inclusion thereby contributing towards poverty reduction efforts. Greenberg (2005) is of the view that ICT is an enabler and a tool that facilitates poverty reduction through its ability to expand economic opportunities, service provision and knowledge base for the poor. The theoretical perspective was supported by Kenny (2002) who noted that ICT are enabling tools which foster income generation and empowerment programmes mainly in the developing countries.

Heeks (2010) argued that ICT indirectly has a positive impact on poverty reduction through promoting freedom, enabling sustainable livelihoods and economic growth. On the other hand, Thomson (2008) noted that ICT guarantees political freedom, transparency, availability of social facilities and economic growth opportunities thereby having an indirect positive influence on poverty alleviation. According to Aftab and Ismail (2015), ICT indirectly reduce poverty through its ability to generate modern knowledge and socioeconomic development for the country, a view which was also supported by Kelles-Viitanen (2003). It is ICT based innovative ideas which can help the people to defeat poverty (Aftab and Ismail, 2015). Obayelu and Ogunlade (2006) also argued that ICT lowers poverty levels through its ability to enhance employment opportunities, cultural, social, educational, and economic advancement programmes.

Etzo and Collender (2010) noted that ICT (mobile telephones) provides a platform that facilitates economic transformation for development. On the other hand, Okpaku (2006) argued that ICT enhances the delivery of poverty reduction linked services such as governance, health, and education as well as business development. 
On the other hand, Jimba (2000) noted that wholesale application of information technologies in African and developing nations not only lead to exploitation of the poor but aggravates the vicious cycle of poverty as it means that governments would have re-directed meagre resources away from addressing pressing urgent national commitments such as health, education, among others. The view was supported by Philip and Tsoi (1988) who argued that African and developing nations have other more pressing problems than wasting the meagre financial resources towards acquiring expensive technology. The view was also shared by Tambo (2003) whose study argued that ICT is not a powerful instrument for poverty alleviation but rather a distraction because it involves the diversion of financial resources from more direct investments that reduce poverty such as education, health and food supply.

\subsection{Information, Communication Technology and Poverty: Empirical View}

Using cross-country statistical analysis, the study by Quibria et al. (2002) had two main objectives. Firstly, to investigate the direct influence of ICT on poverty alleviation and secondly, to find out if there are any indirect benefits of ICT on poverty reduction through economic growth. Their study found out that the impact of ICT on poverty reduction in Asian countries is unclear as it is highly likely that the poor people are not equipped with educational and financial resources to take advantage of the economic advantages presented by new ICT.

A study by Gollakota et al. (2012) also found out that the use and acceptance of telecentres (rural physical facilities that helps the communities access internet and computer services) in rural India had a significant positive impact on poverty alleviation. A study by Haider (2017) also supported the ICT-led poverty reduction nexus. Chikaire et al. (2015) explored the impact of ICT on poverty reduction in the Imo State of Nigeria with primary data collected from 170 small to medium scale farmers using descriptive statistics. The study found out that ICT accelerated access to information on diseases, health and education thereby indirectly contributing to poverty alleviation in the Imo State of Nigeria.

Using trend analysis and descriptive statistics, Urean et al. (2016) explored the impact of ICT on poverty reduction in Romania. Their study revealed that ICT played a critical role in pushing down the levels of poverty in Romania. Gabriels and Horn (2014) investigated using correlation and spatial analysis whether any relationship exist between ICT and poverty reduction in South Africa. Their study revealed that areas which were characterised by high levels of ICT access had lower levels of poverty in South Africa. Consistent with Zulu (1994), maximally tapping into the advantages of ICT is one way through which African and developing countries can take themselves out of poverty.

Using the Vector auto-regression (VAR) approach with World Bank data and other data from various issues of the Pakistan Economic Surveys ranging from 1995 to 2013, Aftab and Ismail (2015) investigated the role played by ICT in helping 
eradicating poverty in Pakistan. They observed that ICT had a significant positive influence on poverty alleviation in Pakistan during the period under study. A study by Kelles-Viitanen (2003) noted that ICT helped to deepen democracy, good governance and in the implementation of sustainable health and education systems. A study by Obayelu and Ogunlade (2006) also found out that ICT infrastructure had a significant positive role in reducing poverty in Nigeria. Without the availability of good ICT, poverty alleviation was found to have been impossible in Nigeria (Obayelu and Ogunlade, 2006).

A study done by Heeks (2014) also revealed that ICT negates the effects of poverty through its ability to improve people's capabilities, livelihoods, and economic opportunities. Carmody (2012) also found out that poverty levels in Africa were lowered down to a greater extent by the rapid spread of ICT in the region. ICT was found by Rahman (2008) to be very useful in helping fighting poverty through three channels: (1) making the poor aware about employment opportunities, (2) alerting the farmer about where they can get the best price for their product and (3) enabling the sick people know about health related issues and different treatment methods. Other empirical studies which revealed that ICT had a deleterious effect on poverty were done by Quibria and Tschang (2001), Ikemelu (2010), Khuhawar et al. (2014) and Chandarsekar and Prakash (2010), and Son et al. (2013).

Khuhawar et al. (2014) investigated the influence of ICT on poverty alleviation in the rural areas of Islamic Republic of Pakistan. The study observed that ICT improved the socio-economic condition and general livelihood thereby providing a platform for poverty eradication of the rural people of the Islamic Republic of Pakistan. Using descriptive statistics with descriptive survey data, Ikemelu (2010) explored the role played by ICT in wealth creation and poverty reduction in Nigeria. Wealth creation and poverty alleviation were found to be some of the benefits brought along by ICT in Nigeria.

\section{Information, Communication Technology and Poverty in BRICS}

Table 1 shows ICT, human capital development, mortality rate and life expectancy trends for BRICS nations during the period from 1994 to 2015.

Three BRICS nations (Brazil, Russia, China) had their internet usage exceeding the overall mean internet usage of $16.69 \%$ whilst India and South Africa's internet usage was below the overall mean. India is an outlier because its internet usage $(5.36 \%)$ fell far much below the overall mean internet usage of $16.69 \%$. Brazil, Russia and China are also characterised by mean human capital development index which is higher than the overall mean human capital development index of 0.70 . BRICS nations whose mean human capital development index was lower than the overall mean human capital development index include India and South Africa. India is an outlier because its mean human capital development of 0.57 is the furthest away from the overall mean human capital development of 0.70 . 
Table 1. ICT, poverty, and education trends in BRICS (1994-2015)

\begin{tabular}{|l|l|l|l|l|}
\hline & $\begin{array}{l}\text { Individuals } \\
\text { using internet } \\
\text { \% of } \\
\text { population } \\
\text { (proxy for ICT) }\end{array}$ & $\begin{array}{l}\text { Human capital } \\
\text { development } \\
\text { index (proxy for } \\
\text { education) }\end{array}$ & $\begin{array}{l}\text { Mean mortality } \\
\text { rate, infant (per } \\
1 \text { 000 births) - } \\
\text { proxy for } \\
\text { poverty }\end{array}$ & $\begin{array}{l}\text { Mean life } \\
\text { expectancy at } \\
\text { birth, total } \\
\text { (years) - proxy } \\
\text { for poverty }\end{array}$ \\
\hline Brazil & 22.99 & 0.75 & 25.02 & 71.64 \\
\hline Russia & 23.23 & 0.78 & 12.94 & 67.22 \\
\hline India & 5.36 & 0.57 & 57.16 & 64.33 \\
\hline China & 16.77 & 0.71 & 22.65 & 73.40 \\
\hline South Africa & 15.10 & 0.67 & 45.56 & 56.93 \\
\hline $\begin{array}{l}\text { Overall } \\
\text { mean }\end{array}$ & $\mathbf{1 6 . 6 9}$ & $\mathbf{0 . 7 0}$ & $\mathbf{3 2 . 6 7}$ & $\mathbf{6 6 . 7 0}$ \\
\hline
\end{tabular}

Source: Compiled by the authors using World Development Indicators.

The mean mortality rate for India (57.16 infants per 1000 births) and South Africa (45.56 infants per 1000 births) are above the overall mean mortality rate of 32.67 infants per 1000 births during the period from 1994 to 2015. Table 1 also shows that the mean mortality rates for the remaining BRICS nations (Brazil, Russia, China) were lower than the overall mean mortality rate of 32.67 infants per 1000 births. Russia, India, and South Africa are the outliers because their mean mortality rates deviated from the overall mean mortality rate by a very wide margin (Table 1). The mean life expectancy at birth for BRICS nations such as Brazil, Russia and China were found to be higher than the overall mean life expectancy at birth of 66.70 years. Table 1 shows that India and South Africa's mean life expectancy at birth is 64.33 years and 56.93 years, respectively. South Africa is the only outlier because its mean life expectancy at birth of 56.93 years is the furthest away from the overall mean life expectancy of 66.70 years for BRICS nations. Overall, the statistics in Table 1 shows a very clear trend. Brazil, Russia and China's internet usage, human capital development and life expectancy are higher than their overall mean values during the period under study (1994 -2015). On the other hand, the mean mortality rates of the same countries are below the overall mean mortality rate of 32.67 infants per 1000 births during the same period.

In Figure 1, it is evident that the increase in the population using internet services corresponds with a decline in the mortality rates in all the five BRICS nations during the period under study. For example, individuals using internet services as a percentage of the population in Brazil went up by 2.83 percentage points, from $0.04 \%$ in 1994 to $2.87 \%$ in 2000 . The period from 2000 to 2005 saw the number of individuals using internet as a percentage of the population in Brazil going up by 18.15 percentage points before further increasing by 19.63 percentage points during the subsequent five-year period (from $21.02 \%$ in 2005 to $40.65 \%$ in 2010). Moreover, Brazil's number of individuals using the internet went up from $40.65 \%$ of the population in 2010 to $58.33 \%$ of the population in 2015 , representing an increase of 17.68 percentage points. Russia's number of individuals using the internet 
increased during the period from 1994 to 2015 (went up from $0.05 \%$ of population in 1994 to $0.53 \%$ of population in 2000 , increased by 13.25 percentage points during the five-year period from 2000 to 2005 , surged by 27.77 percentage points during the five-year period from 2005 to 2010 before registering another positive growth of 27.10 percentage points during the subsequent five-year period (from $43 \%$ of the population in 2010 to $70.10 \%$ of population in 2015).

As for India, internet users went up by $0.52,1.86,5.11$ and 18.50 percentage points during the period from 1994 to 2000, 2000 to 2005, 2005 to 2010 and 2010 to 2015 respectively (Figure 1). China's number of internet users as a percentage of the population increased by (1) 1.77 percentage points (from $0.01 \%$ in 1994 to $1.78 \%$ in 2000), (2) 6.75 percentage points (from $1.78 \%$ in 2000 to $8.52 \%$ in 2005), (3) 25.78 percentage points (from $8.52 \%$ in 2005 to $34.30 \%$ in 2010) and (4) 16 percentage points (from $34.30 \%$ in 2010 to $50.3 \%$ in 2015). South Africa's number of internet users as a percentage of population grew by 5.10 percentage points (from $0.25 \%$ in 1994 to $5.35 \%$ in 2000) and 2.14 percentage points during the subsequent five-year period (from $5.35 \%$ in 2000 to $7.49 \%$ in 2005). The five-year period ranging from 2005 to 2010 saw South Africa's number of individuals using the internet going up by 16.51 percentage points whilst the subsequent five-year period was characterised by a 27.92 percentage points positive growth in the number of internet usage (from $24 \%$ of the population to $51.92 \%$ of the population).

Figure 1. ICT (internet users as a \% of population) and infant mortality rate (per 1000 births) trends for BRICS

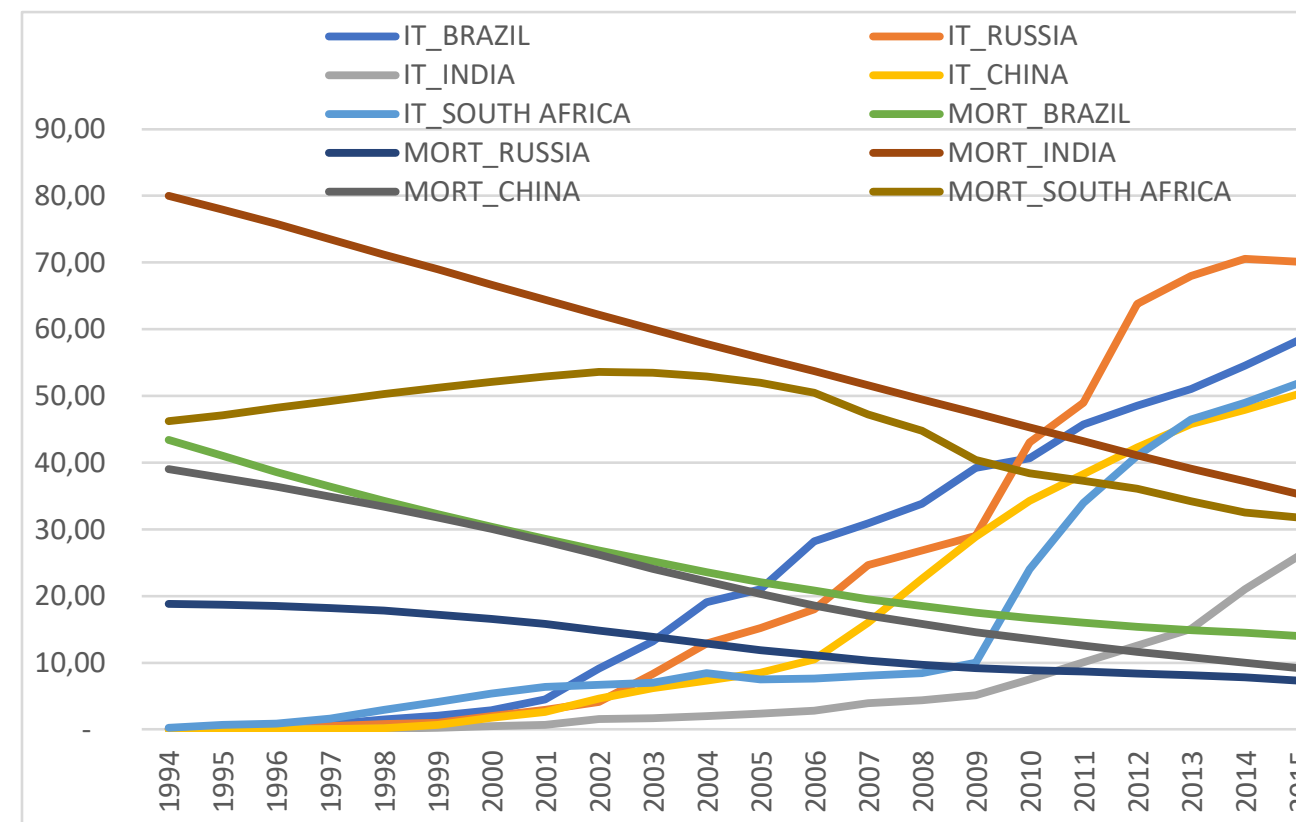

Source: Data obtained from the World Development Indicators. 
Brazil's consistent decline in the mortality rates (infants per 1000 births) during the period from 1994 to 2015 is summarised as follows: The rate went down from (1) 43.40 in 1994 to 30.40 in 2000 (-29.95\%), (2) 30.40 in 2000 to 22.10 in 2005 ($27.30 \%)$, (3) 22.10 in 2005 to 16.70 in $2010(-24.43 \%)$ and (4) 16.70 in 2010 to 14.00 in $2015(-16.17 \%)$. Russia, India, and China's mortality rates during the period under study closely followed the similar downward trend. As for South Africa, the period from 1994 to 2000 saw the mortality rates going up by $12.77 \%$ (from 46.20 infants per 1000 births to 52.10 infants per 1000 births) despite a surge in the number of people using the internet during the same period.

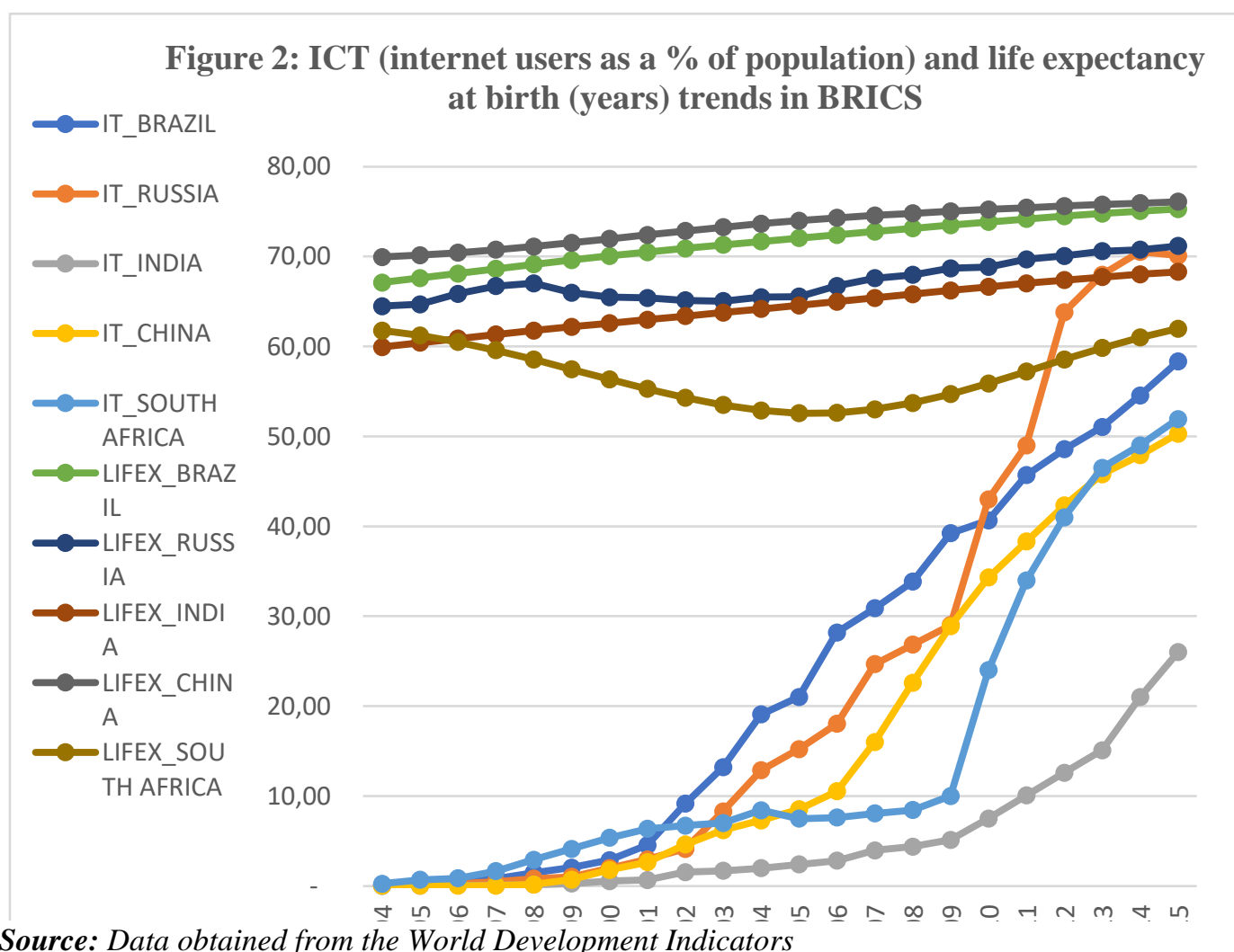

Source: Data obtained from the World Development Indicators

Life expectancy at birth (years) for Brazil, Russia, India and China consistently experienced a positive growth during the period ranging from 1994 to 2015 whereas South Africa's life expectancy at birth (years) trend shows mixed results during the same period under study (Figure 2). Brazil's life expectancy at birth (years) during the period from 1994 to 2015 consistently increased as follows (1) from 67.10 in 1994 to 70.06 in 2000, (2) from 70.06 in 2000 to 72.04 in 2005, (3) from 72.04 in 2005 to 73.84 in 2010 and (4) from 73.84 in 2010 to 75.28 in 2015. On the other hand, Russia's life expectancy at birth (years) consistently went up as follows: (1) $1.58 \%$ (from 64.47 in 1994 to 65.48 in 2000), (2) $0.07 \%$ (from 65.48 in 2000 to 
$65.53 \%$ in 2005), (3) $5.05 \%$ (from 65.53 in 2005 to 68.84 in 2010) and (4) $3.38 \%$ (from 68.84 in 2010 to 71.17 in 2015).

India and China's life expectancy at birth (years) trend during the twenty-two-year period ranging from 1994 to 2015 closely mirrors that Brazil and Russia during the same time frame. As for South Africa, life expectancy at birth (years) plummeted from 61.76 in 1994 to 56.34 in 2000 before further declining by $6.70 \%$ during the period from 2000 to 2005. Life expectancy at birth for South Africa then increased from 52.57 years in 2005 to 55.89 years in 2010 before registering another positive growth of $10.90 \%$ during the subsequent five-year period (from 55.89 years in 2010 to 61.98 years in 2015). Trend analysis shows that there is a linear relationship between (1) internet usage and infant mortality rates and (2) internet usage and life expectancy in the BRICS countries. It is against this background that the current study empirically investigated the relationship between ICT (proxied by internet usage) and poverty (proxied by life expectancy at birth in years).

\section{Methodology}

Although there are several variables in the literature that have an influence on poverty and or define poverty, only few of them have been used in the current study taking into account the following considerations: (1) data availability and (2) variables which were not stationary at first difference such as mortality rates, financial development and gross domestic product (GDP) were excluded from the study (see Table 5). Equation 1 represents an econometric model specification of the poverty function.

$$
\begin{aligned}
& \text { POVERTY }_{i, t}=\beta_{0}+\beta_{1} I T_{i, t}+\beta_{2} \text { EDUC }_{i, t}+\beta_{3} \text { FDI }_{i, t}+\beta_{4} \text { OPEN }_{i, t} \\
& +\beta_{5} \text { INFL }_{i, t}+\mu+_{\varepsilon}
\end{aligned}
$$

where IT, EDUC, FDI, OPEN and INFL stands for ICT, education, foreign direct investment, trade openness and inflation respectively. $\beta_{0}$ is intercept term. Subscript $t$ stands for time whilst subscript $i$ represents country. Eit is the error term whilst the time invariant and unobserved country specific effect is represented by $\mu_{i}$. $\beta_{1}$ to $\beta_{5}$ are the co-efficients of the explanatory variables of poverty. The proxies used for POVERTY, IT, EDUC, FDI, OPEN and INFL are life expectancy at birth, total (years), individuals using the internet (\% of population), human capital development index, net FDI inflow (\% of GDP), total imports and exports (\% of GDP) and inflation consumer prices (annual \%) respectively. 
The second objective of the study was to explore if education enhances the effect of ICT on poverty alleviation. Equation 2 introduces the interaction term whose coefficient is $\beta_{3}$.

$$
\begin{aligned}
& \text { POVERTY }_{i, t}=\beta_{0}+\beta_{1} I T_{i, t}+\beta_{2} E_{\text {EUC }}+\beta_{i, t}\left(I T_{i, t} . E^{2} D U C_{i, t}\right)+\beta_{4} \\
& \text { FDI }_{i, t}+\beta_{5} \text { OPEN }_{i, t}+\beta_{6} I N F L_{i, t}+\mu+\varepsilon
\end{aligned}
$$

Since poverty is proxied by life expectancy, a significant positive co-efficient $\beta_{3}$ means that education improves the influence of ICT on life expectancy. In other words, education would have been found to have enhanced the ability of ICT to lower poverty in the BRICS nations.

Before data was analyzed, it was converted into natural logarithms in order to deal away with extreme values identified in Table 1 and Table 4 (Appendix section), a method consistent with Tsaurai (2018a). Panel root tests, Johansen Fisher Panel Cointegration test and main data analysis constitute this sub-section. Table 5 shows that only life expectancy, ICT, education, foreign direct investment, trade openness and inflation were found to be stationary at first difference. It is against this background that these variables were included in the study (see equation 1 and 2) consistent with Tsaurai (2018b).

\begin{tabular}{|c|c|c|c|c|}
\hline \multicolumn{5}{|l|}{ Level } \\
\hline & LLC & IPS & $\mathrm{ADF}$ & PP \\
\hline LMORT & 1.6169 & 4.4595 & 3.6350 & 4.6889 \\
\hline LLIFEX & -0.7596 & 1.2029 & 6.2493 & 8.0425 \\
\hline LIT & $-2.9988 * * *$ & -0.4353 & 13.4194 & 16.7649 \\
\hline LEDUC & $-3.8188 * * *$ & $-2.5141 * * *$ & $23.1956 * *$ & $35.6885^{* * *}$ \\
\hline LFIN & 3.8443 & 0.4367 & 7.6951 & $37.3230 * * *$ \\
\hline LFDI & -0.6045 & -0.2219 & 14.0040 & $21.4796^{* *}$ \\
\hline LGDP & -0.5656 & -0.0915 & 8.3571 & 2.8220 \\
\hline LOPEN & 0.8429 & 1.3127 & 6.9415 & 6.4769 \\
\hline LINFL & -1.0651 & $-2.2409 * *$ & $21.7215 * *$ & $39.4701 * * *$ \\
\hline \multicolumn{5}{|c|}{ First difference } \\
\hline LMORT & -0.0977 & 0.7388 & 8.6456 & $17.7140^{*}$ \\
\hline LLIFEX & $-2.0682 * *$ & $-5.6228 * * *$ & $47.5085^{* * *}$ & $416.340 * * *$ \\
\hline LIT & $-3.6032 * * *$ & $-3.6679 * * *$ & $32.6763^{* * *}$ & $50.8515 * * *$ \\
\hline LEDUC & $-7.4359 * * *$ & $-6.6533 * * *$ & $54.0042 * * *$ & $288.044 * * *$ \\
\hline LFIN & 0.9137 & $-2.9156 * * *$ & $25.6468 * * *$ & $215.827 * * *$ \\
\hline LFDI & $-2.0242 * *$ & $-2.2820 * *$ & $21.5027 * *$ & $301.964 * * *$ \\
\hline LGDP & -0.0045 & 0.1525 & 7.5761 & 15.2524 \\
\hline LOPEN & $-2.4272 * * *$ & $-2.1850 * *$ & $21.6696^{* *}$ & $55.1716^{* * * *}$ \\
\hline LINFL & $-3.7696 * * *$ & $-4.0431 * * *$ & $33.8191 * * *$ & $77.2317 * * *$ \\
\hline
\end{tabular}

Table 5. Panel root tests-Individual intercept and trend

Source: Authors' compilation from E-Views. 
Note: LLC, IPS, ADF and PP stands for Levin, Lin and Chu; Im, Pesaran and Shin; ADF Fisher Chi Square and PP Fisher Chi Square tests respectively. *, ** and *** denote 10\%, $5 \%$ and $1 \%$ levels of significance, respectively.

Using the Johansen Fisher Panel Co-integration approach, the study went on to investigate whether there is a long run relationship between poverty (proxied by life expectancy) and its explanatory variables, namely ICT, education, FDI, trade openness and inflation (Table 6).

Table 6. Johansen Fisher Panel Co-integration test

\begin{tabular}{|l|l|l|l|l|}
\hline $\begin{array}{l}\text { Hypothesised } \\
\text { No. of CE(s) }\end{array}$ & $\begin{array}{l}\text { Fisher Statistic } \\
\text { (from trace } \\
\text { test) }\end{array}$ & Probability & $\begin{array}{l}\text { Fisher Statistic } \\
\text { (from max- } \\
\text { eigen test) }\end{array}$ & Probability \\
\hline None & 249.2 & 0.00 & 128.7 & 0.00 \\
\hline At most 1 & 153.3 & 0.00 & 84.68 & 0.00 \\
\hline At most 2 & 86.42 & 0.00 & 52.08 & 0.00 \\
\hline At most 3 & 44.79 & 0.00 & 27.32 & 0.00 \\
\hline At most 4 & 28.14 & 0.00 & 19.27 & 0.04 \\
\hline At most 5 & 28.36 & 0.00 & 28.36 & 0.00 \\
\hline
\end{tabular}

Source: Authors' compilation from E-Views.

The results in Table 6 shows that there are at least five co-integrating vectors between and among the variables studied. The interpretation consistent with Tsaurai (2018c) is that there is a long run relationship between and among the variables, a finding which allows the study to proceed to main data analysis (Table 7).

Table 7. Main results -Life expectancy as a dependent variable

\begin{tabular}{|l|l|l|l|}
\hline & Fixed effects & Pooled OLS & $\begin{array}{l}\text { Panel Fully } \\
\text { Modified Least } \\
\text { Squares (FMOLS) }\end{array}$ \\
\hline LIT & $0.0122^{* * *}$ & 0.0115 & 0.0114 \\
\hline LEDUC & $0.1726^{* * *}$ & $0.2316^{* * *}$ & $0.2717 * * *$ \\
\hline INTERACTION TERM & $0.0012^{* * *}$ & 0.0198 & 0.0076 \\
\hline LFDI & 0.000005 & $0.0532^{* * *}$ & 0.0015 \\
\hline LOPEN & -0.0185 & $-0.0845^{* * *}$ & -0.0377 \\
\hline LINFL & 0.0060 & -0.0003 & 0.0118 \\
\hline $\begin{array}{l}\text { Adjusted R-squared } \\
\text { F-statistic }\end{array}$ & 0.9079 & 0.5892 & 0.9184 \\
\cline { 2 - 4 } Prob (F-statistic) & 108.50 & 34.23 & - \\
\cline { 2 - 5 } & 0.0000 & 0.0000 & - \\
\hline
\end{tabular}

Note: ***, ** and * denote 1\%, 5\% and $10 \%$ levels of significance, respectively.

Source: Author's compilation from E-Views.

The fixed effects model shows that both ICT and education had a significant positive influence on life expectancy, in line with majority theoretical and empirical literature. The results are in line with Greenberg (2005) whose study argued that ICT is an enabler and a tool that facilitates poverty reduction through its ability to expand 
economic opportunities, service provision and knowledge base for the poor. The finding also supports Kenny's (2002) view which says that ICT provide enabling tools which foster income generation and empowerment programmes mainly in the developing countries.

The results also resonate with Mihai et al. (2015) whose study noted that more educated people are likely to secure employment easily, they are more productive at the workplace and thereby earn more income, which effectively takes them out of the vicious cycle of poverty. Mihai et al. (2015) also noted that education helps to break the vicious circle of intergenerational poverty transmission.

The interaction term also was found to have had a significant positive impact on life expectancy in BRICS nations. The finding is consistent with Quibria and Tschang (2001) whose study revealed that education and financial strength enable the people to take advantage of the poverty reduction benefits emanating from the use of ICT. Such results give credence to Haider's (2017) assertion that the positive influence of ICT on poverty is not a linear one but relies on other socio-economic factors.

The study found out that FDI had a non-significant positive effect on life expectancy in BRICS nations. The finding is similar to the one observed by Ogunniyi and Igberi (2014) in a study on the impact of FDI on poverty alleviation in Nigeria using the OLS estimation technique. Inflation was also found to have had a non-significant positive impact on life expectancy, a finding which contradicts majority theoretical and empirical literature on inflation-poverty nexus. A non-significant negative relationship running from trade openness towards life expectancy was also detected under the fixed effects approach. The finding shows that trade openness reduced life expectancy or increased poverty levels in the BRICS nations during the period under study, in line with Pradhan and Mahesh's (2014) argument that trade openness or globalisation mainly benefits the rich but further impoverish the poor people. Under conditions of high levels of trade openness, multinational companies have been accused of using their powers to their benefit at the expense of the poor people (Pradhan and Mahesh, 2014).

Under both the pooled OLS and the FMOLS approaches, ICT was found to have had a non-significant positive influence on life expectancy in BRICS nations. The finding resonates with other studies which revealed that ICT reduces poverty through enabling the generating of innovative ideas which help the people to defeat poverty (Aftab and Ismail, 2015). It also agrees with Okpaku's (2006) argument that ICT enhances the delivery of poverty reduction linked services such as education, health, and governance as well as business development.

Consistent with Tilak (2002), who argued that education imparts skills and knowledge and enable one to earn more income, both pooled OLS and FMOLS shows that a significant positive relationship running from education towards life expectancy was observed in BRICS nations. Under both the pooled OLS and the 
FMOLS, the interaction between ICT and education was observed to have had an insignificant positive influence on life expectancy in BRICS nations during the period under study. Although not significant, the finding to a lesser extent implies that education is a channel through which ICT can increase life expectancy or reduce poverty levels in BRICS nations, consistent with Quibria and Tschang's (2001) observations. The pooled OLS approach produced results that show that FDI had a significant positive effect on life expectancy whilst the FMOLS's findings show that the impact of FDI on life expectancy was non-significant positive. The results generally resonate with other more recent research findings of studies done by Ukamaka et al. (2016), Durowah (2017) and Magombeyi and Odhiambo (2018).

The pooled OLS estimation technique produced results which shows a significant negative relationship running from trade openness towards life expectancy. On the other hand, FMOLS shows that trade openness had a non-significant negative impact on life expectancy, a finding which means that trade openness reduced life expectancy or increased poverty levels in BRICS nations. The finding is backed by Pradhan and Mahesh's (2014) argument that trade openness further drives the poor into more poverty because the multinational companies involved under conditions of high trade openness exploits the poor.

According to the pooled OLS, inflation had a non-significant negative influence on life expectancy, a finding which means that inflation increased poverty in BRICS nations. Beetsma (1992) and Albanesi (2007) supported this finding as they argued that higher levels of inflation wipe out the value of the poor's income, thereby making it quite difficult to access a decent medical healthcare which prolongs life. On the contrary, the study detected a non-significant positive relationship running from inflation towards life expectancy, a finding which is in line with United Nations Report (2010). The latter argued that higher levels of inflation lowers the labour cost and real wages hence enabling the firm to employ an increased number of employees.

\section{Conclusion}

The study had two objectives, namely, to investigate the impact of ICT on poverty and to find out if education enhanced the influence of ICT in BRICS nations. Fixed effects, pooled ordinary least squares (OLS) and panel fully modified ordinary least squares (FMOLS) were the three panel data analysis methods used with data ranging from 1994 to 2015 . ICT was found to have alleviated poverty only under the fixed effects approach whilst education had a reduction effect on poverty across all the three econometric estimation techniques used. Although not statistically significant, ICT and the interaction term were found to have reduced poverty under both the pooled OLS and FMOLS. Moreover, consistent with Quibria and Tschang (2001), education was found to be important in enhancing the impact of ICT on poverty alleviation under the fixed effects in BRICS nations. BRICS nations are therefore 
urged to invest more in strengthening education and ICT systems in order to disentangle the people from the vicious cycle of poverty.

\section{References:}

Aftab, M., Ismail, I. 2015. Defeating poverty through education: The role of ICT. Transformations in Business and Economics, 14 (3), 42-59.

Albanesi, S. 2007. Inflation and inequality. Journal of Monetary Economics, 54(4), 10881114.

Beetsma, R. 1992. Essays on exchange rates and inflation. Doctoral Dissertation, Tilburg University.

Carmody, P. 2012. The informationalization of poverty in Africa? Mobile phones and economic structure. Information Technologies and International Development, 8(3), 1-17.

Chandarsekar, K.S., Prakash, C.S.S. 2010. The role of information communication technology in women empowerment and poverty eradication in Kerala. APJRBM, $1(2), 1-16$.

Chikaire, J.U., Ani, A.O., Nnandi, F.N., Godson-Ibeji, C.C. 2015. Analysis of ICT roles in poverty reduction among small and medium scale farmers in Imo State, Nigeria. Library Philosophy and Practice (e-journal), 1284. http://digitalcommons.unl.edu/libphilprac/1284.

Durowah, O. 2017. The role of aid for trade and foreign direct investment in poverty reduction: A panel data analysis of 91 developing countries. Theses and Dissertations, 1187. http://openprairie.sdstate.edu/etd/1187.

Etzo, S., Collender, C. 2010. The mobile phone revolution in Africa: Rhetoric or reality? African Affairs, 109(437), 659-668.

Gabriels, H., Horn, A. 2014. The relationship between access to information and communications technology (ICT) and poverty in South Africa. Africanus: Journal of Development Studies, 44(1), 21-33.

Gollakota, K., Pick, J.B., Sathyapriya, P. 2012. Using technology to alleviate poverty: use and acceptance of telecentres in rural India. ICT for Development, 18(3), 185208.

Greenberg, A. 2005. ICTs for poverty alleviation: Basic tool and enabling sector, ICT for development secretariat. Department of Infrastructure and Economic Cooperation, SIDA.

Haider, M.H. 2017. Impact of communication on poverty reduction. Journal of Scientific Temper, 5(1-4), 21-33.

Heeks, R. 2010. Policy arena: Do information and communications technology contribute to economic development? Journal of International Development, 22(5), 625-640.

Heeks, R. 2014. ICTs and poverty eradication: Comparing economic, livelihoods and capabilities models. Development Informatics Working Paper Series Paper Number 58.

Ikemelu, C.R. 2010. Wealth creation and poverty alleviation in Nigeria: The role of ICT (IT). African Research Review, 4(4), 212-222.

Im, K.S., Pesaran, M.H., Shin, Y. 2003. Testing unit roots in heterogeneous panels. Journal of Econometrics, 115(1), 53-74.

Jimba, S.W. 2000. ICT and the dialectics of poverty in Africa. New Library World, 101(6), 253-262.

Kelles-Viitanen, A. 2003. The role of ICT in poverty reduction. Advisory Board for relations 
with developing countries, Finnish Ministry for Foreign Affairs, Articles 1/2003, 82-94.

Kenny, C. 2002. Information and communication technologies for direct poverty alleviation: Costs and benefits. Development Policy Review, 20(2), 141-157.

Khuhawar, K.H., Jianqiu, Z., Farkhunda, S., Ye, Y. 2014. Crush the poverty by ICT. International Journal of Scientific and Technology Research, 3(4), 250-256.

Kim, V. 2014. The importance of information and communications technology in reducing poverty, Washington and Lee University.

Levin, A., Lin, C.F., Chu, C.S.J. 2002. Unit root tests in panel data: Asymptotic and finitesample properties. Journal of Econometrics, 108(1), 1-24.

Magombeyi, M.T., Odhiambo, N.M. 2018. FDI inflows and poverty reduction in Botswana: An empirical investigation. Cogent Economics and Finance, 6(1), 1-15.

Mihai, M., Titan, E., Manea, D. 2015. Education and poverty. Procedia Economics and Finance, 32, 855-860.

Pradhan, B.K., Mahesh, M. 2014. Impact of trade openness on poverty: A panel data analysis of a set of developing countries. Economics Bulletin, 34(4), 2208-2219.

Obayelu, A.E., Ogunlade, I. 2006. Analysis of the uses of ICT for gender empowerment and sustainable poverty alleviation in Nigeria. International Journal of Education and Development using ICT, 2(3), 45-69.

Ogunniyi, M.B., Igberi, C.O. 2014. The impact of foreign direct investment on poverty reduction in Nigeria. Journal of Economics and Sustainable Development, 5(14), 73-89.

Okpaku, J.O. 2006. Leapfrogging into the information economy: Harnessing information and communications technologies in Botswana, Mauritania and Tanzania. In L. Fox and R. Liebenthal (Eds), Attacking Africa's poverty: Experience from the ground, Washington, D.C., World Bank.

Philip, G., Tsoi, S. 1988. Regulation and deregulation of telecommunications: the economic and political realities. Journal of Information Science, 14(6), 329-334.

Quibria, M.G., Tschang, T. 2001. ICT and poverty: An Asian perspective. JADBI Research Paper Series, Number 12.

Quibria, M.G., Tschang, T., Reyes-Macasaquit, M. 2002. New information and communication technologies and poverty: Some evidence from developing Asia. Journal of the Asia Pacific Economy, 7(3), 285-309.

Rahman, M.A. 2008. Role of ICT in rural poverty alleviation. Masters' Degree in Development Studies. BRAC Development Institute, BRAC University. Unpublished Thesis.

Son, L., Noja, G.G., Ritivoiu, M., Tolteanu, R. 2013. Education and economic growth: An empirical analysis of interdependencies and impacts based on panel data. Timisoara Journal of Economics and Business, 6(19), 39-54.

Tambo, I. 2003. Integrating ICT in development programmes, www.oecd.org/dac/ict.

Thomson, M. 2008. ICT and development studies: Towards development 2.0. Journal of International Development, 20(6), 821-835.

Tilak, J.B.G. 2002. Education and poverty. Journal of Human Development, 3(2), 191-207.

Tsaurai, K. 2017. Is foreign portfolio equity investment inspired growth hypothesis relevant in emerging markets? Euro Economica, 36(2), 78-90.

Tsaurai, K. 2018a. Is the complementarity between education and financial development a panacea for poverty reduction? The Journal of Developing Areas, 52(4), 227-248.

Tsaurai, K. 2018b. Is the interaction between human capital and financial development one 
of the determinants of FDI in emerging markets? International Journal of Education Economics and Development, 9(1), 24-37.

Tsaurai, K. 2018c. Investigating the determinants of human capital development in emerging markets. International Journal of Education Economics and Development, 9(2), 172-181.

Ukamaka, A.T., David, E.T., Moses, O.I. 2016. Foreign direct investment and poverty reduction in Nigeria. International Journal of Business and Management Invention, 5(6), 19-28.

United Nations. 2010. Rethinking poverty, Report on the World Social Situation, United Nations, New York.

Urean, C.A., Lacatus, V.D., Mocean, L. 2016. Information and communications technology as a poverty reduction tool. Annals of the Constantin Brancusi University of Targu Jiu, Economy Series, (1), 107-113.

World Bank. 2012. ICT for greater development impact -World Bank Group strategy for information and communication technology, 2012-2015.

Zulu, S. 1994. Africa's survival plan for meeting the challenges of ICT in the 1990s and beyond. Libri, 44(1), 77-94.

\begin{tabular}{|c|c|c|c|c|c|c|c|c|}
\hline \multicolumn{9}{|c|}{$\begin{array}{l}\text { Appendix section: } \\
\text { Table 2: Correlation analysis }\end{array}$} \\
\hline & MORT & IT & EDUC & FIN & FDI & GDP & OPEN & INFL \\
\hline MORT & 1.00 & & & & & & & \\
\hline IT & $-0.5937 * * *$ & 1.00 & & & & & & \\
\hline EDUC & $-0.7846 * * *$ & $0.3269 * * *$ & 1.00 & & & & & \\
\hline FIN & 0.0942 & $0.1740 *$ & -0.1230 & 1.00 & & & & \\
\hline FDI & $-0.406 * * *$ & 0.1439 & $0.2367^{* *}$ & 0.1174 & 1.00 & & & \\
\hline GDP & $-0.584 * * *$ & $0.8419 * * *$ & 0.4820 **** & 0.0889 & 0.1421 & 1.00 & & \\
\hline OPEN & $-0.250 * * *$ & 0.0935 & 0.0834 & $0.2845^{* * * *}$ & -0.011 & 0.0246 & 1.00 & \\
\hline INFL & 0.0328 & -0.1101 & 0.1280 & -0.0656 & -0.153 & -0.0396 & -0.134 & 1.00 \\
\hline
\end{tabular}

Note: $* * *, * *$ and $*$ denote $1 \%, 5 \%$ and $10 \%$ levels of significance, respectively.

Source: Authors' compilation from E-Views.

\begin{tabular}{|c|c|c|c|c|c|c|c|c|}
\hline & LIFEX & IT & EDUC & FIN & FDI & GDP & OPEN & $\begin{array}{l}\text { INF } \\
\text { L }\end{array}$ \\
\hline LIFEX & 1.00 & & & & & & & \\
\hline IT & $0.3894 * * *$ & 1.00 & & & & & & \\
\hline EDUC & $0.4229 * * *$ & $0.3269 * * *$ & 1.00 & & & & & \\
\hline FIN & $-0.2258^{* *}$ & $0.1740^{*}$ & -0.1230 & 1.00 & & & & \\
\hline FDI & $0.5112 * * *$ & 0.1439 & $0.237^{* *}$ & 0.1174 & 1.00 & & & \\
\hline GDP & $0.2178 * *$ & $0.8419^{* * * *}$ & $0.482 * * *$ & 0.0889 & 0.1421 & 1.00 & & \\
\hline OPEN & $-0.3124 * * *$ & 0.0935 & 0.0834 & $0.285^{* * * *}$ & -0.0105 & 0.0246 & 1.00 & \\
\hline INFL & -0.0046 & -0.1101 & 0.1280 & -0.0656 & -0.1527 & -0.0396 & -0.1343 & 1.00 \\
\hline
\end{tabular}

Note: $* * *, * *$ and $*$ denote $1 \%, 5 \%$ and $10 \%$ levels of significance, respectively.

Source: Authors' compilation from E-Views. 


\begin{tabular}{|l|l|l|l|l|l|l|l|l|l|}
\hline \multicolumn{2}{|l|}{ Table 4: Descriptive statistics } \\
\hline & MORT & LIFEX & IT & EDUC & FIN & FDI & GDP & OPEN & INFL \\
\hline Mean & 32.67 & 66.70 & 16.69 & 0.70 & 93.9 & 2.27 & 4399 & 43.2 & 32.3 \\
\hline Median & 31.8 & 67.5 & 7.50 & 0.72 & 80.03 & 2.15 & 3451 & 46.8 & 6.65 \\
\hline Maximum & 80.0 & 76.1 & 70.5 & 0.82 & 193.4 & 6.01 & 14487 & 72.87 & 2076 \\
\hline Minimum & 7.30 & 52.6 & 0.01 & 0.45 & 20.81 & 0.17 & 353.3 & 15.64 & 0.26 \\
\hline Std. Dev. & 18.78 & 6.39 & 19.65 & 0.08 & 51.30 & 1.45 & 3693 & 14.69 & 200 \\
\hline Skewness & 0.56 & -0.54 & 1.13 & -0.66 & 0.39 & 0.45 & 1.04 & -0.23 & 9.89 \\
\hline Kurtosis & 2.41 & 2.44 & 3.06 & 2.66 & 1.91 & 2.32 & 3.28 & 1.91 & 101.4 \\
\hline Jarque-Bera & 7.23 & 6.75 & 23.23 & 8.63 & 8.24 & 5.87 & 20.06 & 6.40 & 46178 \\
\hline Probability & 0.03 & 0.03 & 0.00 & 0.01 & 0.02 & 0.05 & 0.00 & 0.04 & 0.00 \\
\hline Observations & 110 & 110 & 110 & 110 & 110 & 110 & 110 & 110 & 110 \\
\hline
\end{tabular}

Source: Authors' compilation from E-Views. 